\title{
Genetic Diversity of Duabanga moluccana Blume from Two Provenances in West Nusa Tenggara Revealed by Microsatellite markers
}

Siti Halimah Larekeng $^{1 *}$, Yusniar ${ }^{1}$, Muh. Restu ${ }^{1}$, Rismawati ${ }^{2}$, Yuni Fitri Cahyaningsih ${ }^{3}$, Mirza Arsiaty Arsyad ${ }^{4}$, Arif Nirsatmanto ${ }^{5}$

${ }^{1}$ Biotechnology and Tree Breeding Laboratory, Faculty of Forestry, Universitas Hasanuddin, Makassar, Indonesia.

$22^{\text {nd }}$ Regional of Seed/Seedling Forest Tree, South Sulawesi, Indonesia

3 Indonesian Tropical Fruit Research Institute, Solok, West Sumatera, Indonesia.

${ }^{4}$ Faculty of Agrotechnology, Halu Oleo University, Kendari, Indonesia

5 Centre for Forest Biotechnology and Tree Improvement (CFBTI), Yogyakarta, Indonesia

*Corresponding author's e-mail: sitih5h.82@gmail.com

How to Cite: Larekeng, S.H., Yusniar., Restu, M., Rismawati., Cahyaningsih, Y.F., Arsyad, M.A., and Nirsatmanto, A. (2020). Genetic Diversity of Duabanga moluccana Blume from Two Provenances in West Nusa Tenggara Revealed by Microsatellite markers. Int. J. Agr. Syst. 8(1): 34-43

\begin{abstract}
Duabanga moluccana Blume or locally known as Rajumas, is a tree species that suitable for building materials, pulp, and plywood. The information about genetic diversity is required for the conserving of this species. Here, we elucidated the genetic diversity of D. moluccana from two provenances in West Nusa Tenggara, Indonesia. Microsatellite markers investigated the genetic diversity, and the Analysis of Molecular Variance (AMOVA) was performed for assessing molecular variance within and between the populations using GenAlEx 6.5 software. Four microsatellite markers successfully amplified 12 randomly selected samples and produced polymorphic DNA bands. Those primers were DMAG10, DMAG09, DMACAG01, and DMTCAC11. High genetic diversity was detected in the populations with 0.54 of mean expected heterozygosity (He). The genetic variation among individuals was $100 \%$, whereas there were no genetic variations among populations and within the individuals.
\end{abstract}

Copyright @ 2020 IJAS. All rights reserved.

\section{Keywords:}

D. moluccana; Microsatellite; Genetic Diversity

\section{Introduction}

Analysis of genetic diversity is an initial step in plant breeding. Genetic diversity can be analyzed using a molecular marker for identifying the genotype of an individual. One of those markers for this purpose is microsatellite, or known as Simple Sequence Repeat (SSR)(Nugroho et al., 2015). SSR is a co-dominant molecular marker having high accuracy, polymorphism (Miah et al., 2013). The principle of genetic diversity using DNA marker is analyzing the polymorphism of a species based on the amplified 
DNA bands. The data will be in the form of phylogenetic dendrogram, genetic distance, and polymorphism information content. Phylogenetic and genetic distance data are utilized for clustering the individuals, whereas polymorphism information content will be use for determining polymorphism of a marker (Larekeng, et al., 2016).

SSR markers have been used in numerous studies on germplasm conservation, phylogenetic analysis, plant and animal breeding, and gene identification on the specific trait (Rosmayati, et al., 2016). They are often employed in the genetic studies, due to high polymorphism, specific loci, easy to reproduction, low DNA needs, as well as co-dominant character (Pugh et al., 2004).

Some genetic diversity studies have been successfully conducted using SSR markers those were on Agathis (Ebi, 2015), Ebony (Larekeng, et al., 2019a), D. moluccana (Liew, et al., 2016), Teak (Mohammad, et al., 2017), and Jabon merah ( Larekeng, et al., 2019). But only a few information on D. moluccanas' even though the information is greatly needed for its breeding programs.

D. moluccana is an important pioneer tree species that well adapted in West Nusa Tenggara Province, Indonesia (Supriyanto \& Prakasa, 2011). The species were wide range distribution including some islands in Indonesia, Jawa Island, Kalimantan Island, Sulawesi Island, and Maluku. This species can also be found in New Guinea (Papua Nugini) and Philippine. Its wood can be utilized as industrial raw materials, pulp and temporary building materials. Evaluation of the level and structure of genetic diversity in endangered species is important for plant breeding and genetic resource conservation programs (Xu, Cheng, Xian, \& Peng, 2016) and D. moluccana is more important for conservation. Based on this information, the genetic diversity study on D. moluccana is needed for supporting its breeding and conservation programs.

\section{Materials and Methods}

\subsection{Sample Collection and DNA Isolation}

Sample collection was done at Rarung Forest Area for Special Purpose (FASP), West Nusa Tenggara. This area is the reseach area of Mataram Forest Research Office. Duabanga populations planted in this location were from Lombok and Calabai provenances. The analyzed samples consisted of 50 individuals from Lombok and 55 individuals from Calabai. The leaves were collected and kept in the plastic bags in the cooler box contained ice that maintained the freshness of the leaves. The leaves were then stored in the freezer until the DNA isolation process. DNA isolation was carried out by Cetyl Trimethyl Ammonium Bromide (CTAB) method by modification (Ismail, et al., 2016).

\subsection{Primer Selection}

Primer selection is conducted to acquire primers which produce amplified DNA bands. The clearness of the produced bands, as well as number of loci, could be obtained by this process. It is carried out by randomly selecting 12 different DNA and amplifying them using 10 SSR primers at the same PCR condition. Thus the optimal condition and the band variation of each primer will be obtained. The selection of specific primer is determined by observing the clearness and the ease of scoring on the produced bands (Larekeng et al., 2015). 
Table 1. SSR Primer name and sequence for primer selection of D. moluccana Blume

\begin{tabular}{|c|c|c|c|c|c|}
\hline No & Lokus & $\begin{array}{l}\text { Repeat } \\
\text { Motif }\end{array}$ & Primer Sequence $\left(5^{\prime}-3^{\prime}\right)$ & $\begin{array}{l}\operatorname{Tm} \\
\left({ }^{\circ} \mathrm{C}\right)\end{array}$ & $\begin{array}{l}\text { PCR Product } \\
\text { size (bp) }\end{array}$ \\
\hline \multirow{2}{*}{1} & \multirow{2}{*}{ DMAC01* } & \multirow{2}{*}{$\begin{array}{c}(\mathrm{GA})_{3} \mathrm{CACC} \\
(\mathrm{GA})_{7}\end{array}$} & F: GTACAGCACGCACATGACAC & \multirow{2}{*}{56.1} & \multirow{2}{*}{$193-210$} \\
\hline & & & R: GTAGGCCGCTATCAAACCAG & & \\
\hline \multirow{2}{*}{2} & \multirow{2}{*}{ DMAC06* } & \multirow{2}{*}{$(\mathrm{TAG})_{3}(\mathrm{TAA}$} & F: GGCTGAGGTCATGTCAGAGTC & \multirow{2}{*}{54.6} & \multirow{2}{*}{$230-250$} \\
\hline & & & R: AAATTGGCACACGCATTTAG & & \\
\hline \multirow{2}{*}{3} & \multirow{2}{*}{ DMAG09* } & \multirow{2}{*}{$(\mathrm{AG})_{10}$} & F: GGATTCTGTTCACGATTTTCG & \multirow{2}{*}{54.2} & \multirow{2}{*}{$200-275$} \\
\hline & & & R: TCACCGCCAACCTCTCTCAAG & & \\
\hline \multirow[b]{2}{*}{4} & \multirow{2}{*}{ DMAG04* } & \multirow{2}{*}{$\begin{array}{l}(\mathrm{GAT})_{3} \mathrm{GTT} \\
(\mathrm{GAT})_{3}\end{array}$} & F: AGAAGCTGGCAGAAAAATGC & \multirow{2}{*}{54.2} & \multirow{2}{*}{$150-250$} \\
\hline & & & R: GCGAGAGAAAGCAAAAGGTC & & \\
\hline \multirow{2}{*}{5} & \multirow{2}{*}{ DMAG05* } & \multirow{2}{*}{$(\mathrm{CT})_{19}$} & F: TGTGTGCTCATTGCTTTCTTG & \multirow{2}{*}{54.5} & \multirow{2}{*}{$237-350$} \\
\hline & & & R: GGCTCTCTCTGTCTATTTTGG & & \\
\hline \multirow[b]{2}{*}{6} & \multirow[b]{2}{*}{ DMAG06* } & \multirow{2}{*}{$\begin{array}{c}(\mathrm{CT})_{4} \mathrm{TTTT} \\
(\mathrm{CT})_{3} \mathrm{G} \\
(\mathrm{TTTTC})_{2}\end{array}$} & F: TCATCACGAGACGACTGACC & \multirow[b]{2}{*}{54.8} & \multirow[b]{2}{*}{$225-275$} \\
\hline & & & R:GGGGTACAATCTAAATTGATCGAG & & \\
\hline \multirow{2}{*}{7} & \multirow{2}{*}{ DMAG10* } & \multirow{2}{*}{$(\mathrm{CT})_{8}$} & F: TTCCTCTCCTCGTTTCTTG & \multirow{2}{*}{54.5} & \multirow{2}{*}{$180-250$} \\
\hline & & & R: TGCGTCTCTTCTTCCTTGAAC & & \\
\hline \multirow{2}{*}{8} & DMACACO1* & KAC & $\mathrm{F}:(\mathrm{AC})_{6}(\mathrm{AG})_{5}$ & 545 & 230300 \\
\hline & DIVIACAGUI & $(A L)_{6}(A G) 9$ & R:TGAGCTCATTGTAGTAGAGAACAAG & 34.0 & $230-500$ \\
\hline 9 & & (ATA) & F: GGGGTACGGTTGAGTACAGC & 577 & $200-280$ \\
\hline 9 & DVICACO4^ & $(\mathrm{A} \perp \mathrm{A})_{7}$ & R: AGTGAAGCGCAGGGTATTTG & $5 \% .7$ & $200-280$ \\
\hline 10 & DМТС $\triangle C 11 *$ & & F: CTGGCTATAACAGGGCCAAA & 550 & \\
\hline 10 & DVКСАС & $(\mathrm{GA}) 19$ & R: CACACACACACTATACTCCACCTC & 35.9 & 15 \\
\hline
\end{tabular}

Source: Liew., et al 2016

\subsection{SSR Data Analysis}

The separation of the amplified DNA generates DNA bands on the gel. The presence of the band can be analyzed directly. If the band is absent, the scoring will be 0 . Meanwhile, the shortest band size will be scored as 1, and the following numbering will be sorted according to the band sizes. Allele positions at a certain locus are determined by the presence of the bands using SSR marker (Mulsanti, 2011).

Data were tabulated and then analyzed using molecular software. Parameters of genetic diversity were the number of detected alleles $\left(N_{a}\right)$, observed heterozygosity $\left(H_{\circ}\right)$, expected heterozygosity $\left(H_{g}\right)$, and percentage of genetic diversity which was calculated using GenAlEx 6.5 software (Peakall \& Smouse, 2012) :

$$
H_{o}=\frac{N_{o} \text { of Hets }}{N}
$$

Notes: $N_{\sigma}$. of Hets is number of heterozygote individuals in a population, $\mathrm{N}$ is the total number of individuals in a population.

$H_{E}$ is:

$$
H_{E}=1-\sum_{i=1}^{n} p_{i}^{2}
$$

Notes: $p_{i}$ is $i^{\text {th }}$ allele frequency in a population. 
Darwin 6.0 software is employed to cluster the individuals using Unweighted PairGroup Methode Arithmetic (UPGMA). This clustering is called clustering analysis. The result of this analysis presents the dendrogram that shows the relationship among individuals (Widyatmoko, et al., 2011).

The capability of the locus to distinguish genotypes is determined by the value of Polymorphism Information Content (PIC). This value is calculated using an online program at http://www.genomics.liv.ac.uk/animal/protocoll.html with the following equation (Hildebrand, et al., 1992) :

$$
\text { PIC }=1-\sum_{i=1}^{n} p_{i}^{2}-\left(\sum_{i=1}^{n} p_{i}^{2}\right)^{2}+\sum_{i=1}^{n} p_{i}^{4}
$$

\section{Results and Discussion}

\subsection{Primer Selection}

Primer selection step using ten SSR primer pairs on D. moluccana showed four primers were able to amplify the DNA. The primer were DMAG10, DMAG09, DMACAG01 and DMTCAC11. The results of primer selection using DMACAG01 presented in Figure 1. DMACAG01 primer produced four clear, bright, and polymorphic bands. So that these primes would be used in next analysis.

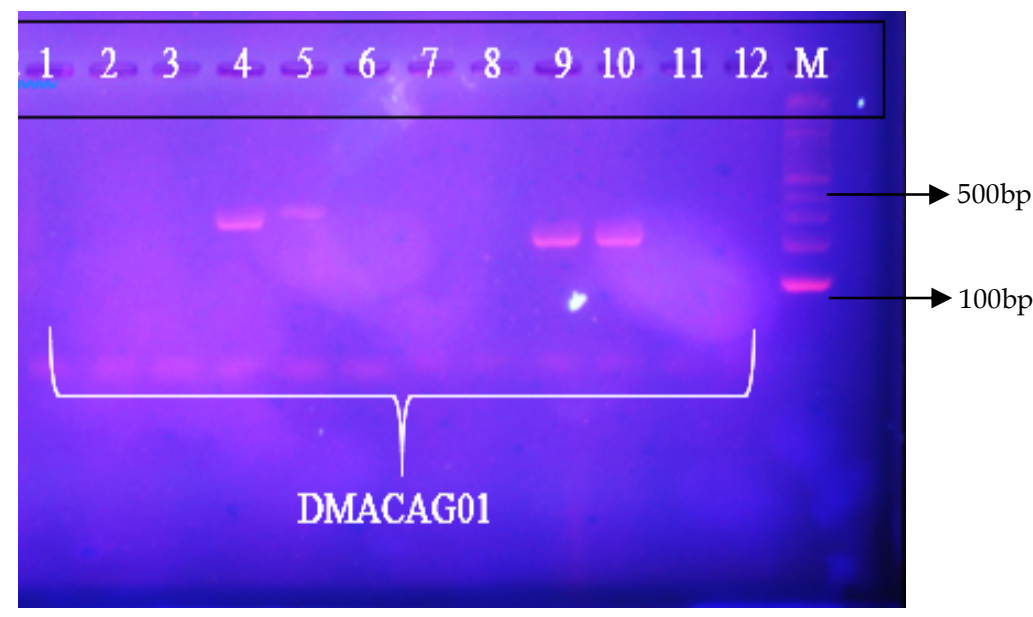

Figure 1. Electropherogram of PCR products using primer DMACAG01

Table 2. The selected SSR primers

\begin{tabular}{lccc}
\hline \multicolumn{1}{c}{ Locus } & Repetitive motive & $\mathrm{T}_{\mathrm{a}}\left({ }^{\circ} \mathrm{C}\right)$ & PCR product size $(\mathrm{bp})$ \\
\hline DMAG10* $^{*}(\mathrm{CT})_{8}$ & 53.9 & $250-300$ \\
DMAG09* $^{*}$ & $(\mathrm{AG})_{10}$ & 54.8 & $200-800$ \\
DMACAG01* $^{*}$ & $(\mathrm{AC})_{6}(\mathrm{AG})_{9}$ & 58.2 & $250-300$ \\
DMTCAC11 $^{*}$ & $(\mathrm{GA})_{19}$ & 60.4 & 300 \\
\hline
\end{tabular}

\subsection{Analysis of genetic Diversity}

Genetic diversity analysis has several parameters, namely number of detected alleles $\left(\mathrm{N}_{\mathrm{a}}\right)$, expected heterozygosity $\left(H_{\mathrm{e}}\right)$, and observed heterozygosity $\left(H_{o}\right)$ that were calculated using GenAlEx 6.5 software (Peakall \& Smouse, 2012). The data were 
obtained from manually scoring the amplified bands and tabulated them into GenAlEx 6.5 dan Polymorphism Information Content Calculator (PIC) software (Table 3).

Table 3. $\mathrm{Na}$, He and PIC value Lombok and Calabai Provenance

\begin{tabular}{ccccccc}
\hline \multirow{2}{*}{ Primer } & \multicolumn{6}{c}{ Provenance } \\
\cline { 2 - 7 } & $\mathrm{Na}$ & $\mathrm{He}$ & $\mathrm{PIC}$ & $\mathrm{Na}$ & $\mathrm{He}$ & PIC \\
\cline { 2 - 7 } & 3 & 0.413 & 0.354 & 3 & 0.452 & 0.366 \\
DMAG09 & 3 & 0.508 & 0.450 & 3 & 0.540 & 0.483 \\
DMAG10 & 2 & 0.500 & 0.375 & 3 & 0.625 & 0.550 \\
DMACAG01 & 3 & 0.637 & 0.565 & 3 & 0.559 & 0.559 \\
DMTCAC11 & 2.8 & 0.519 & 0.436 & 3 & 0.562 & 0.490 \\
\hline Mean & & & & & &
\end{tabular}

The number of detected alleles in the Lombok Provenances was 11 alleles, whereas the Calabai Provenances were 12 alleles. The produced bands by each primer were range from 2 - 3 bands in each provenance. DMACAG01 generated the lowest number of bands in the Lombok provenance (two bands). DMAG09, DMAG10, and DMTCAC11 produced three bands in Lombok and Calabai Provenances. It indicated that the forth primers were polymorphic; thus, those primes can be used in further analysis for both provenances.

Means of expected heterozygosity $\left(H_{\epsilon}\right)$ in Lombok and Calabai Provenances were 0.519 and 0.562 , respectively, that indicated high genetic diversity in both provenances. $H_{\theta}$ of each locus using DMTCAC11 $\left(H_{e}=0.637\right.$ and 0.630; Mean of $\left.H_{e}=0.634\right)$ was relatively higher than $H_{e}$ of DMACAG01 ( $H_{e}=0.500$ and 0.626; Mean of $\left.H_{e}=0.563\right)$, DMAG10 $\left(H_{e}=0.508\right.$ and 0.540; Mean of $\left.H_{e}=0.524\right)$, and DMAG09 $\left(H_{e}=0.431\right.$ dan 0.452; Mean of $\left.H_{e}=0.442\right)$. DMTCAC11, DMACAG01, and DMAG10 had $H_{e} \geq 0,5$ and high genetic diversity. Genetic diversity using DMAG09 showed $H_{e}<0.5$ in both provenances. The $H_{e} \geq 0,5$ means high genetic diversity, while $H_{e}<0,5$ indicates low genetic diversity (Nurtjahtjaningsih, et al., 2013).

Mean of $H_{e}$ in both provenances proved high genetic diversity in D. moluccana (0.54) compared to other tree species of Ebony that had low mean of $H_{e}(0.26)$ (Larekeng et al., 2019). The presence of a higher number of alleles also indicated that the populations presented more diversity (0.58) compared to the mean genetic diversity in Brazilian pepper fruit $(\mathrm{He}=0.30)$. However, this $\mathrm{He}$ value is considered low when compared to the values reported for the same species and other tropical tree species using microsatellite markers (Fidelis, et al., 2016). The high genetic diversity among individuals in D. moluccana is caused by the pattern of seed distribution and pollination. The seeds are distributed by wind due to very fine seed size, and thus they could spread widely.

Means of PIC using DMAG09, DMAG10, DMACAG01, and DMTCAC11 were 0.360, $0.467,0.463$, and 0.562 , respectively. PIC ranged from 0.36 to 0.56 and denoted moderate informative for analyzing the genetic diversity of D. moluccana. The criteria of PIC on a primer are: PIC $>0.5$ is high informative, $0.5>$ PIC $<0.25$ is moderate informative, and PIC $<0.5$ is low informative (Botstein, et al., 1980). 


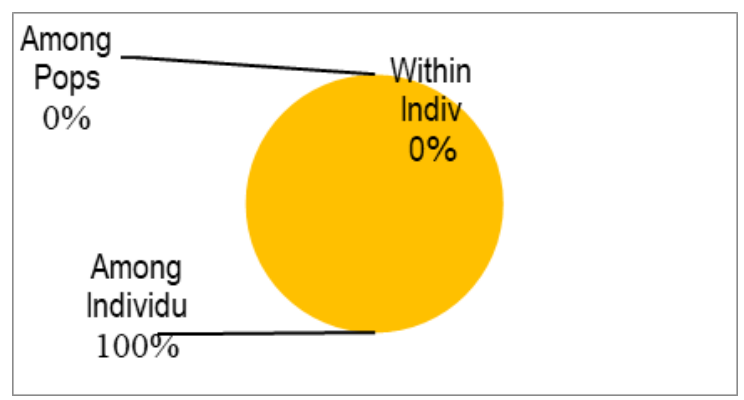

Figure 2. Analysis Molecular of Variance (AMOVA) in both provenances of D. moluccana using four primers

Variation among individuals was $100 \%$, whereas none of variations among provenances and within individuals were found (Figure 2). The analysis showed that no variation was observed between populations. Meanwhile, $100 \%$ variation was detected among individuals, and no variation was also observed within individuals in the population. It was assumed that the genetics of the individuals in Lombok provenance was similar to that of in Calabai provenance. The same case in extremely low genetic diversity both within and among populations, similar to the levels documented in Ptychosperma for the regionally endangered palm and Livistona carinensis (Shapcott, Dowe, \& Ford, 2009). Genetic diversity within populations is predicted to be lost over generations in small populations due to genetic drift as well as sampling effects during population crashes.

\subsection{Relationship among Individuals in Two Provenances}

The genetic relationship between both provenances (Figure 3) showed that 105 individuals were grouped into three clusters. The first, second, and third clusters consisted of 67 individuals, 36 individuals, and two individuals, respectively.

Figure 3 depicts the first and second clusters consisted of individuals from both provenances. The third cluster only consisted of individuals from Calabai Provenance that had very distinct characters. The cluster analysis did not divide based on the provenances (among population $=0 \%$ ).

The first and second clusters encompassed sub-clusters that grouped the close relationship of individuals. The first cluster had sub-clusters formed from the same provenance. There was no genetic variation within individuals in the provenance (within individuals $=0 \%$ ). The individuals among provenances $/$ populations grouped in different clusters that showed 100\% of genetic variation (among individuals $=100 \%$ ). This result is similar to another study on Schinus terebinthifolius Raddi fruits of Brazil that showed no genetic differentiation between southeast and northeast regions. However, there is genetic differentiation among the populations (0.35). Genetic differentiation among the populations was statistically different from zero ( $q p=0.28$, with confidence interval of 0.16 to 0.39 ), indicating that $28.6 \%$ of genetic diversity was among the populations (Fidelis et al., 2016). 


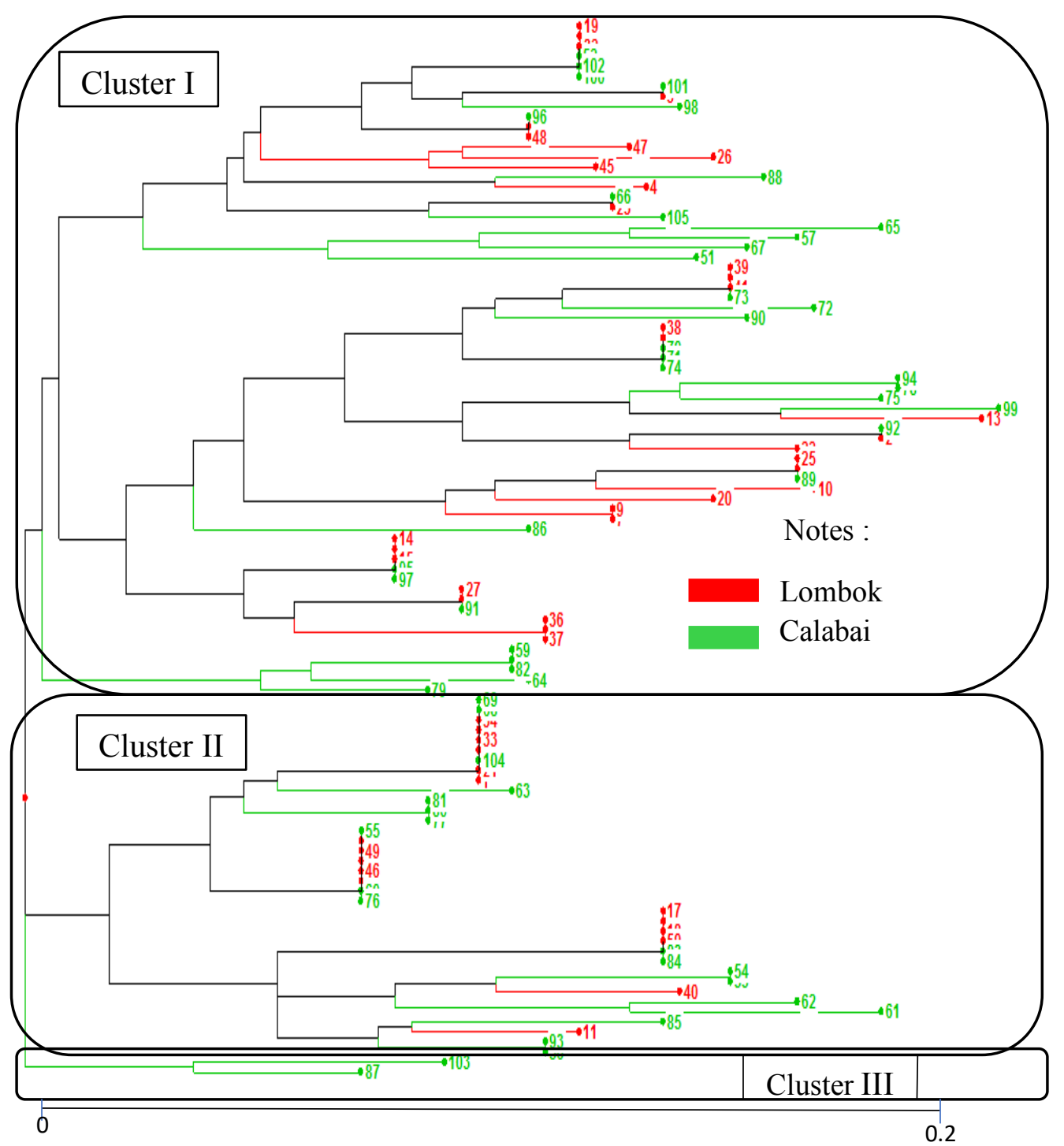

Figure 3. Dendrogram of genetic relationship in Lombok and Calabai Provenances using four SSR primers

Reffering to the results from this study, D. moluccana population requires a high genetic diversity in the future uses. This is because genetic diversity is the crucial indicator in plant breeding for improving genotypes with superior characteristics, such as resistance to disease and extreme adverse environmental conditions. It can also be used maximize the effort to improve specific character on a particular species. The results also revealed that SSR markers could efficiently clarify the existent genetic variability in D. moluccana. This is similar to the result in another study on olive, and the identified genetic variability is somewhat in coincidence with the geographical distribution of olive genotypes (Bahmani et al., 2016).

In addition, the results imply genetic conservation using molecular marker approaches are able to amplify local genotypes for analyzing genetic diversity in D. moluccana. Such studies have also been conducted in Diospyros celebica (Restu, et al., 2017), and Anthocephalus macrophyllus (Larekeng, et al., 2018). Another study developed the first molecular database for eastern Mediterranean pomegranate germplasm using new SSR markers and represented a crucial step in gathering knowledge of the resources 
available for the genetic improvement of pomegranate. Knowledge of the information content of the SSR primer pairs used here to detect polymorphisms among these pomegranate accessions will allow the selection of the most efficient markers (Caliskan et al., 2017).

\section{Conclusion}

The primers utilized for genetic diversity of D. moluccana were DMAG09, DMAG10, DMACAG01, and DMTCAC11. The analysis of genetic diversity of D. moluccana in both provenances showed a high level of genetic diversity.

\section{Acknowledgments}

The author would like to thank for The 2nd Regional Seed/Seedling Forest Office (BPTH Wilayah 2) team to collect all samples and support the research.

\section{References}

Bahmani, A., Dadpour, M., Asadi-abkenar, A., \& Zare-nahandi, F. (2016). Use of Microsatellite Markers for Genetic Diversity Analysis of Olive Germplasm in the North of Iran, 8(1), 27-31.

Botstein, D., White, R. L., Skolnick, M., \& Davis, R. W. (1980). Construction of a Genetic Linkage Map in Man Using Restriction Fragment Length Polymorphism. Am J Hum Gen, 32, 314-331. Retrieved from papers2://publication/uuid/0B80518EA22B-41F3-BE43-171F51007E42

Caliskan, O., Bayazit, S., Oktem, M., \& Ergul, A. (2017). Evaluation of the genetic diversity of pomegranate accessions from Turkey using new microsatellite markers. Turkish Journal of Agriculture and Forestry, 41, 142-153. https://doi.org/10.3906/tar-1606-124

Ebi, E. (2015). Keragaman Genetik Jenis Agathis sp Berbagai Provenansi Berdasarkan Penanda Mikrosatelit Simple Sequense Repeat (SSR). Skripsi. Fakultas Kehutanan Universitas Hasanuddin Makassar, 16, 1-55. https://doi.org/10.1377/hlthaff.2013.0625

Fidelis, J., Mann, R., Santos, R., \& Carvalho, D. d. (2016). Structure and genetic diversity of natural Brazilian pepper populations ( Schinus terebinthifolius Raddi ). Genetics and Molecular Research, 15(2), 1-14. https://doi.org/10.4238/gmr.15028123

Hildebrand, C. E., Torney, D. C., \& Wagner, R. P. (1992). Informativeness of Polymorphic DNA Markers. In Mapping the Genome (Vol. 20, pp. 100-102). Los Alamos Science. https:/ / doi.org/10.1016/S0923-1811(98)00020-6

Ismail, M., Halimah, L. S., Hengky, N., \& Sudarsono, S. (2016). Xenia negatively affecting kopyor nut yield in Kalianda Tall kopyor and Pati Dwarf kopyor coconuts, 28(9), 644-652. https:// doi.org/10.9755/ ejfa.2015-07-552

Kristianto Nugroho, Reflinur, Puji Lestari, Ida Rosdianti, Rerenstradika T. Terryana, Kusmana, dan I. M. T. (2015). Keragaman Genetika Empat Belas Aksesi Kentang (Solanum tuberosum L.) Berdasarkan Marka SSR dan STS. Agrobiogen, 11(2), 4148 . 
Larekeng, Siti Halimah., Restu, Muh., Gusmiaty, Gusmiaty., Rismawati, R. (2016). Polymorphism of Simple Sequence Repeat Regions of Sulawesi Ebony ( Diosphyros celebica Bakh .) in Experimental Forest of Hasanuddin University Provenance. Agrotech Journal, 1(1), 37-44.

Larekeng, S. H., Restu, M., Arif, A., Cahyaningsih, Y. F., \& Mukti, J. (2019). A genetic approach to study mating system on Jabon Merah (Anthocephalus macrophyllus Roxb.) from three different provenances in South Sulawesi. In IOP Conference Series: Earth and Environmental Science (Vol. 235). Institute of Physics Publishing. https:// doi.org/10.1088/1755-1315/235/1/012049

Larekeng, Siti Halimah, Restu, M., Gusmiaty, G., Millang, S., \& Bachtiar, B. (2018). Moderate Level of Genetic Diversity in Anthocephalus macrophyllus Roxb, an endemic tree of Sulawesi and Its Implication in Conservation. International Journal of Agriculture System, 6(1), 74-81.

Larekeng, Siti Halimah, Restu, M., Susilowati, A., \& Rachmat, H. H. (2019). Genetic diversity of parental and offspring population in ebony (Diospyros celebica bach) revealed by Microsatellites marker. International Journal on Emerging Technologies, 10(2), 178-185.

Liew, K., Ho, W., Pang, S., \& Abdullah, J. (2016). Development, Polymorphism and Cross-Species Transferability of Genomic SSR Markers in Duabanga Moluccana, an Indigenous Tree Species from Sarawak. OnLine Journal of Biological Sciences, 16(1), 57-70.

Miah, G., Rafii, M. Y., Ismail, M. R., Puteh, A. B., Rahim, H. A., Islam, K., \& Latif, M. A. (2013). A review of microsatellite markers and their applications in rice breeding programs to improve blast disease resistance. International Journal of Molecular Sciences, 14(11), 22499-22528.

Mohammad, N., Mahesh, S., Jain, Y. K., \& Ansari, S. A. (2017). Effect of discrete ( individual ) and mixed ( bulk ) genomic DNA on genetic diversity estimates and population structure in Teak ( Tectona grandis L . f . ), 55(January), 44-48.

Mulsanti, I. W. (2011). Identifikasi dan evaluasi kemurnian genetik benih padi hibrida menggunakan marka mikrosatelit. Bogor.

Nurtjahtjaningsih, I., YPBC Widyatmoko, A., \& Rimbawanto, A. (2013). Karakterisasi Dan Aplikasi Penanda Mikrosatelit Pada Beberapa Species Eucalyptus. Jurnal Pemuliaan Tanaman Hutan, 7(2), 107-118. https://doi.org/10.20886/jpth.2013.7.2.107-118

Peakall, R., \& Smouse, P. E. (2012). GenALEx 6.5: Genetic analysis in Excel. Population genetic software for teaching and research-an update. Bioinformatics, 28(19), 25372539. https://doi.org/10.1093/bioinformatics/bts460

Pugh, T., Fouet, O., Risterucci, A.-M., Brottier, P., Abouladze, M., Deletrez, C., ... N'Goran, J. A. K. (2004). A new cacao linkage map based on codominant markers: development and integration of 201 new microsatellite markers. Theoretical and Applied Genetics, 108(6), 1151-1161.

Restu, M., Gasir, G., \& Larekeng, S. H. (2017). High outcrossing rate and pollen dispersal distance of diospyros celebica Bakh. (Ebenaceae), an endemic tree species in Sulawesi Island, Indonesia. Biotropia, 24(3). https://doi.org/10.11598/btb.2017.24.3.562

Rosmayati, R., Rahmawati, N., \& Astari, R. P. (2016). Genetics Diversity Analysis of Progeny F 3 Soybean ( Glycine max L .) Tolerant Salinity Using Microsatellite Markers. Journal of Natural Sciences Research, 6(20), 46-51.

Shapcott, a., Dowe, J. L., \& Ford, H. (2009). Low genetic diversity and recovery implications of the vulnerable Bankoual?? Palm Livistona carinensis (Arecaceae), 
from North-eastern Africa and the Southern Arabian Peninsula. Conservation Genetics, 10, 317-327. https://doi.org/10.1007/s10592-008-9582-5

Supriyanto, S., \& Prakasa, K. . (2011). Pengaruh zat pengatur tumbuh Rootone-F terhadap pertumbuhan stek Duabanga moluccana Blume. Jurnal Silvikultur Tropika, 03(01), 59-65.

Widyatmoko, A., Nurtjahjaningsih, I., \& Prastyono. (2011). Study on the Level of Genetic Diversity of Diospyros celebica, Eusideroxylon zwageri And Michelia spp . Using RAPD Markers. Bogor.

Xu, X., Cheng, F., Xian, H., \& Peng, L. (2016). Genetic diversity and population structure of endangered endemic Paeonia jishanensis in China and conservation implications. Biochemical Systematics and Ecology, 66, 319-325. https://doi.org/10.1016/j.bse.2016.05.003 